\title{
Adoption of innovations in harvesting methods of the grape: A case study in Charikar and Bagram districts of Parwan province, Afghanistan
}

\author{
Zafaruddin Dadkhwah $^{1 *}$, Kürşat Demiryürek ${ }^{1}$ \\ ${ }^{1}$ Ondokuz Mayıs University, Faculty of Agriculture, Department of Agricultural Economics, Samsun, \\ Turkey
}

\begin{abstract}
The main objectives of this study were to determine the extent of innovation in the grape harvest, and the rate of familiarity and usability of innovations by farmers in Parwan province. The data were collected as primary data, included face to face interviews with 120 grape growers and local authorities in 20 villages spread across the two districts of Charikar and Bagram provinces of Parwan, Afghanistan. The data was analyzed by (SPSS 22) Package. According to the results, the size of agricultural land, land allocated to grape production have the most similarities; however, the findings show that grape yield was impressed by the application of farmers' innovations and knowledge by the user of innovation in the harvest stage grape production. The membership of farmers in agricultural organizations is very weak, and only $8.2 \%$ of the farmers have membership in the organization. And also, the advantages and disadvantages of using innovations were evaluated. The advatages were evaluated by six options (Saving Time, Increasing demand for the product, Wastes Reduction in the product, Better management, Easy harvest, Employment of less laborer), and all of them given high importance (HI). The disadvantages were evaluated in four options, of which only the the item "Not economic" was given (HI) while the remaining three disadvantages were in (LI) category. Familiarity and usability of innovations have different results; most of the farmers are familiar with innovations. However, the application of innovations is less than it is familiarity
\end{abstract}

Keywords: Innovation, Grape Harvest Methods, Afghanistan, Parwan

\section{Introduction}

The topic of this study is to analyze the adoption of innovations in harvesting methods of grapes. This case study was conducted in Charikar and Bagram district of the province of Parwan. In this study, we will discuss the adoption of innovations in the grape harvest, applicable innovations, and inapplicable innovations in Afghanistan and also the role of government and NGOs in introducing, spreading and supporting is one of the major and controversial issues.

In Afghanistan, the traditional production, harvesting, and post-harvesting systems are among the most fundamental problems that have a very negative effect on the production and standardization of grapes. Afghanistan's grapes are a major source of export both as fresh produce and dried as raisins, and due to this, the use of innovations in the production, harvest and postharvest stage is very crucial. In Afghanistan, to solve the problems in the production, harvest, and post-harvest steps, both the government, along with various NGO's have activities that support these issues. Some of these include activities such as (CAD-F) in the case of vineyard chewing cases, house raisins, farmers training for the correct use of innovations at harvesting stage grapes, and training on the supply of their products to the national and international markets. NHLP has been in the process of changing the traditional vineyard cultivating systems into the $\mathrm{T}$ system and training of the new innovation of the grape harvesting process for farmers. (GIZ) also works on other projects for agribusiness and rural markets and also conducts visual education in the 
grape value chain. (AMIP) which operates in the development of small processing facilities and bundling of the market for horticultural products(Anonymous 2019).

Afghanistan's farmers are not in a good economic state. Many face poverty in their daily lives, and the season of cultivation brings them additional challenges like borrowing to meet some needs. In recent years, the majority of farmers have learned about innovation and utilization by government and NGOs; however, most are not be able to buy new harvesting equipment. Lack of sales markets for the product is one of the main factors that farmers don't have interests in the adoption of innovation. Farmers, who are in a better economic state and have better knowledge, use innovations in the harvest stage and believe in the effectiveness of innovations (Khaliq \& Boz, 2018).

\section{Material and Methods}

Multiple analytical methods were used to analyze the data in this study. These included descriptive and inferential statistics. The descriptive data analysis involved measures of central tendency. The inferential statistics had included correlation analysis. The statistical analysis of the data was carried out with the aid of Statistical Package for the Social Science (SPSS). The analysis had included technological capabilities and innovations.

Innovation score in this work used the basic idea of the Innovation Index is to assign a single numerical value to the set of innovations of every farmer such numerical valuation must assign higher numbers to innovations that push the technological frontier or to innovations that are relatively rare within the subsector, here it is referred to the degree of adoption of a particular innovation among the farmers (Ariza et al., 2013). Demiryurek et al., (2014) developed an innovation sustainability index of Dasgupta, (1968) by using not only the number of innovation but also included years of adoption. When the innovation index value increases, the sustainability of innovation that farmer has been adopted increase consequently. Therefore, farmers whose have higher index value can be said are more innovative. (Demiryurek et al., 2015).

In this study, we calculated the Innovation Score of the grape harvester's in

Parwan, Afghanistan as:

Innovation Scores $=$ Number of years of adoption $\times$ Number of adopted innovation

Total of innovation.

\section{Research findings}

\subsection{Age}

In table 6.2, 120 farmers were interviewed. These farmers are divided into three age groups, the first age group being those 40 years and younger, the second being 60-40 years age range, the third being 60 years old and older. The participants in this study are as old as 80 being the oldest one and the youngest being 18 years old.

As noted in table 3.1, 120 farmers were surveyed in this study as grape producers, $29.2 \%$ of the farmers are in the first age group, $57.5 \%$ of farmers are included in the second group, and $13.3 \%$ of them consist of the third age group. The highest percentage of the farmers consists of the second group, with the average age being 47.15. According to the findings of this study, most of the grape producers are over 40 years old, and young producers represent a smaller demographic.

Table 3. 1. Farmer's Age

\begin{tabular}{|l|r|r|r|}
\hline Age groups & Frequency & \% & Mean \\
\hline$\leq 40$ & 35 & 29.2 & \multirow{2}{*}{$47.15+-12.76$} \\
\hline $40-60$ & 69 & 57.5 & 13.3 \\
\hline$\geq 60$ & 16 & & \\
\hline
\end{tabular}

\subsection{Education level}

Knowledge is a key principle in the agriculture sector. It means farmers can be more productive using agricultural knowledge and the precise use of production factors (Fane 1975). The knowledge level of grape producers in this section is divided into six groups according to knowledge. The first group includes illiterate producers. The second group includes producers who can read and write with no educational background, the third group includes producers who graduated from elementary school, the fourth group includes producers who have graduated from secondary 
school, the fifth group consists of manufacturers who graduated from high school, and the sixth group includes producers who graduated from university.

According to table $3.2,41.7 \%$ of producers are illiterate and belong to the first group. Farmers of the second group can read and write, and they form about $5.8 \%$ of the total, farmers of the third group who have finished elementary school form

Table 3.2. Education level

\begin{tabular}{|l|r|r|}
\hline Education level groups & Frequency & \% \\
\hline Illiterate & 50 & 41.7 \\
\hline Read and writing & 7 & 5.8 \\
\hline Primary school & 7 & 5.8 \\
\hline Secondary school & 14 & 11.7 \\
\hline High school & 33 & 27.5 \\
\hline University & 9 & 7.5 \\
\hline Total & 120 & 100.0 \\
\hline
\end{tabular}

\subsection{Membership in Agricultural Organizations}

Social units are organizations that work collectively to meet their needs. All of these organizations have a management structure that divides responsibilities and power among its members. These organizations have an open environment and act according to group decisions(MacDonald 1963).

Table 3.3 shows that $90.8 \%$ of the producers do not belong to any organization, $7.5 \%$ of the farmers are members of the cooperative, and $1.7 \%$ of the farmers are members of the associations. According to the research on agriculture innovation systems of Cassava production in Kajo-Keji of South Sudan which was conducted on 80 farms, 42 farmers had membership in organizations; the remaining 38 are not members of any organization(Ajak 2016)

Table 3.3. Organizational Membership

\begin{tabular}{|l|r|r|}
\hline Variable & Fre & $\%$ \\
\hline Yes & 11 & 8.2 \\
\hline No & 109 & 90.8 \\
\hline
\end{tabular}

According to Table 3.4 that shows the Organizational membership of farmers, from $8.2 \%$ members of the organization, $7.5 \%$ of farmers about $5.8 \%$ of total farmers. About $11.7 \%$ of farmers have graduated from secondary school, and they form the fourth group. The fifth group included high school graduated, and the rate was $27.5 \%$. The five groups consist of the highest percentage after the first group, the remaining 7.5 percent, which are related to the sixth group, they have graduated from college and have higher education.

have cooperatives membership, and the remaining $1.7 \%$ of farmers have the association membership.

Table 3.4. Organizational Membership

\begin{tabular}{|l|r|r|}
\hline Organization & Frequency & \% \\
\hline Cooperative & 9 & 7.5 \\
\hline Association & 2 & 1.7 \\
\hline Total & 120 & 100.0 \\
\hline
\end{tabular}

\subsection{Health Insurance}

Insurance, in the simplest definition, is a method of transferring risk(DeNavas-Walt 2010). Insurance is one of the most important tools in the agricultural sector because it can encourage farmers to produce more comfortably. Agriculture is a risky sector, and its exposure to natural disasters and environmental stresses is very high (Club 2018).

Table 3.5 shows that in this research, $60 \%$ of the grape producers did not know the meaning of insurance, and the remaining $40 \%$ did not have insurance. A study conducted in the Bafra district of Samsun province included 37 respondents, of which 26 were insured, and 11 were not insured (Abdurahman 2015).

Table 3.5. Health Insurance 


\begin{tabular}{|l|r|r|}
\hline Groups & Frequency & \% \\
\hline I don't know & 72 & 60 \\
\hline I don't have & 48 & 40 \\
\hline \multicolumn{3}{|c|}{ Mean = 1.4 } \\
\hline
\end{tabular}

\subsection{Farm Size and the Land Ownership Status}

Earth is the basis of natural resources (Rasmussen 1996). The efficiency of each ecosystem depends on the type and quality of land use. Land usage serves many different purposes, whether it is residential land, agricultural land (water fields and rugged land), forests, and sometimes unusable land. In general, the natural resources of a country can predict the future of that nation (Douroudian 2017).

In this research, farmers' lands are categorized into five groups. These include private/personal land, rented land, given to rent, and kept to partnership land and partnership land. After evaluating this study, two types of land rented land and kept to partnership have been fixed to zero.

According to figure 3.1, agricultural lands are divided into three groups. The highest percentage belongs to the personal land, which accounts for $72 \%$ of the land. The other group is rental land, which accounts for $24 \%$ of the land, and the third is the partnership land that forms $4 \%$ of the agricultural land.

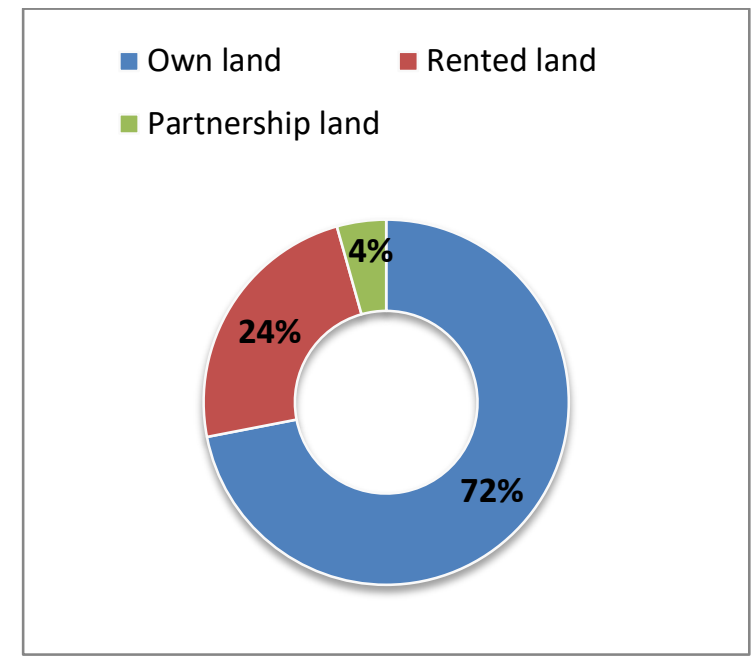

Figure 3. 1. Types of Lands

\subsection{Debt status of the farm}

Table 3.6 represents the state of debt for farmers. In the research, the findings indicated that farmers' had no relationships with the bank, Cooperatives, and government. The farmers are borrowing from friends, relatives, and acquaintances. The average loan is worth 23,065.42 AFN, and the average period of the loan is 6.89 months. Of the farmers that were surveyed, $89.2 \%$ of the farmers were borrowing money, while $10.8 \%$ of the farmers were not.

Table 3.6. Debate status of the farm

\begin{tabular}{|l|r|r|r|}
\hline Groups & \% & Amounts & Months \\
\hline Use debate & 89.2 & $23,065.42$ & 6.89 \\
\hline Do not use debate & 10.8 & & \\
\hline Total & 100.0 & & \\
\hline
\end{tabular}

\subsection{Use of innovation in the harvest stage of}

\section{grape}

Innovation in its new meaning is epoch-making, creative, and new ideas(Card-F 2018). In other words, innovation can mean stopping a service, system, or process that is inefficient or old. Innovation can be exploited by introducing new products, services, and processes that have more effective models. With the use of innovations, it is possible to get more productive (Startups 2017).
According to table 3.7, this study discusses the use of innovations at the grape harvesting stage. There are two options, Yes and No. The first option indicates that $22.5 \%$ of farmers do not use innovations at the grape harvesting stage, and $77.5 \%$ of farmers use innovations at the grape harvesting stage. 
Table 3.7. Use of innovation in Harvest Stage of Grape

\begin{tabular}{|l|r|r|r|}
\hline & State & Frequency & \% \\
\hline \multirow{2}{*}{ Usage Status } & No & 27 & 22.5 \\
& Yes & 93 & 77.5 \\
\cline { 2 - 4 } & \multicolumn{2}{c}{ Mean $=\mathbf{0 . 7 7 5 0}$} \\
\hline
\end{tabular}

\subsection{Familiarity and Usability of Innovations}

Table 3.8 discusses the familiarity and usage of innovations for grape harvesting. These innovations are used in different stages of harvest, which includes the testing for sugar level, berry

size, color, cutting, field packing, clipping, packing, and packaging houses.

The findings show that $38.3 \%$ of farmers are familiar with testing for sugar levels in this innovation at the harvesting stage; however, it applies to $6.7 \%$ of farmers. Berry size is familiar for $43.3 \%$ of farmers; however, this innovation is applicable to $11.7 \%$ of farmers. Considering that the color of grapes is an essential step in the harvesting stage of the products, it is a familiar aspect to the highest percentage of farmers at $96.7 \%$, with $87.5 \%$ of farmers accepting this stage. The cutting stage is familiar for $98.3 \%$ of farmers, and it is applicable for $94.2 \%$ of farmers. Field packing stage is done primarily in the field,

Table 3.8. Familiarity and usability of innovations

\begin{tabular}{|l|r|r|r|r|}
\hline \multirow{2}{*}{ Types of innovation } & \multicolumn{2}{|c|}{ Familiar } & \multicolumn{2}{c|}{ Usability } \\
\cline { 2 - 5 } & Frequency & \% & Frequency & \% \\
\hline Testing for sugar level & 46 & 38.3 & 8 & 6.7 \\
\hline Berry size & 52 & 43.3 & 14 & 11.7 \\
\hline Color & 116 & 96.7 & 105 & 87.5 \\
\hline Cutting & 118 & 98.3 & 113 & 94.2 \\
\hline Field packing & 111 & 92.5 & 107 & 89.2 \\
\hline Clipping & 107 & 89.2 & 103 & 85.8 \\
\hline Packing & 114 & 95.0 & 105 & 87.5 \\
\hline Packhouse & 83 & 69.2 & 9 & 7.5 \\
\hline
\end{tabular}

with $92.5 \%$ of farmers being familiar with this stage, and $89.2 \%$ of them are packing their products on the farm, and this is applicable for them. The Clipping Stage is one of the basic stages of harvesting for good marketing and preventing product rotting. This stage of the innovation is a familiar factor for $89.2 \%$ of farmers, and it is applicable for $85.8 \%$ of them. Most of the time, the Packing stage is completed in the field, $95 \%$ of farmers are familiar with this stage, and it is applying to $87.5 \%$ of farmers. Packing houses are among the innovations that are least accessible to farmers. In the past two years, a packaging and processing center for produce was opened in Parwan province. The results of this study, however, show because of the lack of availability and existence of packaging houses, many farmers have resulted in packing their products on the field. Of the farmers surveyed, $69.2 \%$ of farmers are familiar with packaging houses, but only $7.5 \%$ of farmers use this innovation.

In this research, the minimum usage of innovation is $6.7 \%$, and it's in the testing for sugar level category. The maximum use of these innovations was in the cutting stage, with $94.2 \%$ usage. 


\subsection{Familiarity and Usability of New Harvest tools}

Table 3.9 discusses the familiarity and usability of new harvest tools. These tools are used in different stages of harvest, which include (handheld refractometer, digital refractometer, caliper, sizing rings, cutting shears, food thermometer, Basket, carton, clipping scissors, and tarpaulin).

The findings show that $37.5 \%$ of the farmers are familiar with a handheld refractometer; however, its usage applies to $5.8 \%$ of farmers. Digital refractometer is a familiar tool for $36.7 \%$ of farmers; however, this tool is applicable to $4.2 \%$ of farmers. A caliper is a familiar tool for $42.5 \%$ of farmers, and $21.7 \%$ of them use this tool. The sizing rings are familiar to $40 \%$ of farmers, and it is applicable for $12.5 \%$ of farmers. Cutting shears is familiar to $90 \%$ of farmers and is used by $100 \%$ of farmers. The knowledge and usage of a food thermometer are not high among the tools as it is familiar for $35 \%$ of farmers and only used by $0.8 \%$ of them. Baskets can be one of the most basic tools as it is familiar for $98.3 \%$ of farmers and used by $92.5 \%$ of farmers. Carton is familiar for $98.3 \%$ of farmers, and it is used by $96.7 \%$ of farmers. Clipping scissors is familiar with $93.3 \%$ of farmers and used by $87.5 \%$ of farmers. Tarpaulin is the last tool that is familiar to a high percentage of farmers at $87.5 \%$ but only used by $30 \%$ of farmers.

Table 3.9. Familiarity and Usability of New Harvest tools

\begin{tabular}{|l|r|r|r|r|}
\hline \multirow{2}{*}{ Types harvest tools } & \multicolumn{2}{|c|}{ Familiar } & \multicolumn{2}{c|}{ Usable } \\
\cline { 2 - 5 } & Frequency & \% & Frequency & \% \\
\hline Handheld refractometer & 45 & 37.5 & 7 & 5.8 \\
\hline Digital refractometer & 44 & 36.7 & 5 & 4.2 \\
\hline Calliper & 51 & 42.5 & 26 & 21.7 \\
\hline Sizing rings & 48 & 40.0 & 15 & 12.5 \\
\hline Cutting shears & 120 & 100 & 108 & 90.0 \\
\hline Food thermometer & 42 & 35.0 & 1 & 0.8 \\
\hline Basket & 118 & 98.3 & 111 & 92.5 \\
\hline Carton & 118 & 98.3 & 116 & 96.7 \\
\hline Clipping scissors & 112 & 93.3 & 105 & 87.5 \\
\hline Tarpaulin & 105 & 87.5 & 36 & 30.0 \\
\hline
\end{tabular}

six items were placed in the 3.50-4.49 high

\subsection{Advantages of Appling Innovation}

Table 3.10 presents the Advantages of Appling Innovation (Objective 1). Based on the advantage of applying the innovation scale described above,

Table 3.10. Advantages of Appling Innovation importance (HI) categories. The six items were as follows; "saving time", " "increase of demand for the product", "waste reduction in the product", "better management", "easy harvest", "employment of fewer laborers". The remaining category is zero.

\begin{tabular}{|l|l|r|r|r|}
\hline Rank & Variable & Mean & SD & Category \\
\hline 1 & Saving Time & 4.4917 & .67358 & HI \\
\hline 2 & Increasing of demand for the product & 4.2583 & .62840 & HI \\
\hline 3 & Wastes Reduction in the product & 4.2583 & .87251 & HI \\
\hline 4 & Better management & 4.2333 & .69492 & HI \\
\hline 5 & Easy harvest & 4.1417 & .79172 & HI \\
\hline 6 & Employment of less laborer & 3.8333 & .91057 & HI \\
\hline
\end{tabular}

\subsection{Disadvantages of Applying Innovation}

Table 3.11 presents the disadvantages of Applying innovation (Objective 1). Based on the disadvantage of Appling innovation scale from four items the first one "not economic", is in the (HI) category the others are in the (LI) category, which is: "takes more time", "the need of many 
workers", “digress in production". The

remaining category is zero.

Table 3.11. Disadvantages of Appling Innovation

\begin{tabular}{|l|l|r|r|r|}
\hline Rank & Variable & Mean & SD & Category \\
\hline 1 & Not economic & 3.8167 & .97862 & HI \\
\hline 2 & Takes more time & 2.1250 & 1.07346 & LI \\
\hline 3 & Needs of many workers & 2.0417 & 1.02405 & LI \\
\hline 4 & Digress in production & 1.5500 & .84863 & LI \\
\hline
\end{tabular}

were merchants, $30 \%$ were retailers, $27 \%$ were

\subsection{Customer's Channels}

Figure 3.2 examines the first farmer's market after crop production. The farmers market occurs after harvesting of their products in which there are five market merchants, retailers, wholesalers, exporters, and packager. Of the total buyers, $31 \%$ wholesalers, $10 \%$ were exporters, and the remaining $2 \%$ were packagers. Lack of sufficient access to these markets is the main problem faced by farmers in the part of sales. The absence of government support during the farmer's market season also causes harm to farmers in terms of product sales.

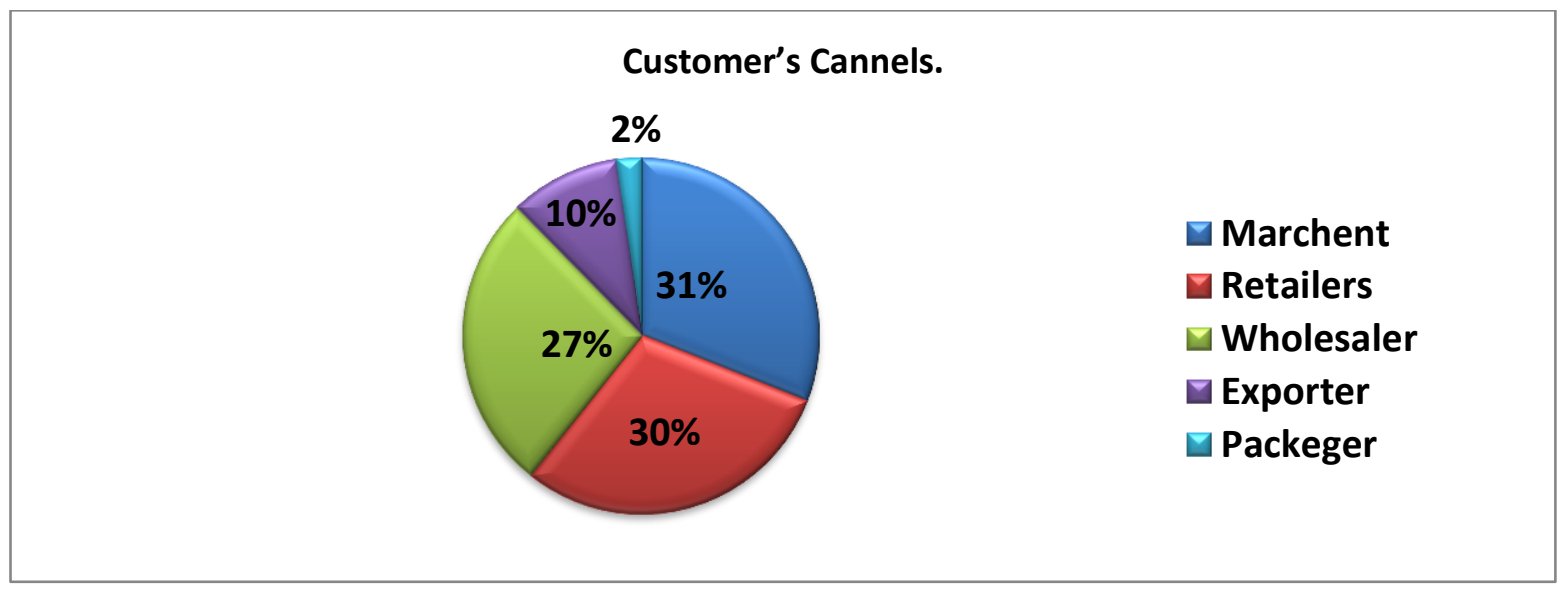

Figure 3.2. Customer's Channels

\section{Conclusion}

The main objective of this research is to determine the extent of innovation in the grape harvest and the rate of familiarity and usability of innovations by farmers in Parwan province. This study can help producers make informed decisions for the use of innovations in the production and harvest of grapes. It covers the main issues related to extending harvest methods and familiarity and usability innovation by farmers. In the Socioeconomic characteristics of farmers in terms of age, most of the farmer was in the middle age terms of age, in terms of education, the majority of them were illiterate. According to the place of residence, all of the grape producers lived in villages, and

none of them had any off-farm occupation.
In terms of experience in agriculture, annual income, household size of farmers, there was no significant difference; however, in terms of health insurance of farmers, no one had health insurance. The farm size and the land ownership status of farmers the most of land was own land of farmers, land value hade different value that location and productivity of land can be the reasons for it. The farmers are familiar with the innovations at the harvest stage and believe in the effectiveness of these innovations. Farmer's knowledge of tools and innovations varies. Most farmers have been introduced to the harvesting tools and tools, and they are familiar, but most farmers do not use their innovations and methods.

Customer's channels of farmers contain merchant, retailer, wholesaler, exporter, and packager between these channels has not significantly 
different; most of the farmers randomly select their customers.

\section{References}

[1] Abdurahman, M. A. 2015. 'The Comparison of Agricultural Knowledge and Information Systems (Akis) For Adopters and Non-Adopters of Good Agricultural Practices in Bafra District of Samsun, Turkey', Ondokuz Mayis University.

[2] Ajak, J. D. A. 2016. 'Agricultural Innovation Systems : Case Of Cassava Producers In Kajo-Keji County, South Sudan', MASTER'S DEGREE THESIS Ondokuz Mayis University.

[3] Anonymous. 2019. 'Programs \& Projects of Ministry of Agriculture, Irrigation and Livestock', Accessed 08.22.2019. https://mail.gov.af.

[4] Card-F. 2018. 'grape value chain', Accessed 25.05.2019. http://www.cardf.gov.af

[5] Club, Young Journalist. 2018. 'Farmers' disapproval of agricultural insurance.'. https://www.yjc.ir/fa/news/6709532.

[6] DeNavas-Walt, Carmen. 2010. Income, poverty, and health insurance coverage in the United States (2005) (Diane Publishing).

[7] Douroudian, H.R., Douroudian, A.,. 2017. 'Sociological and ecological implications of the excessive change in the use of agricultural lands', Scientific Journal of Land Management: 5.

[8] Fane, G. 1975. 'Education and the managerial efficiency of farmers', The Mit Press, 57: 4.

[9] MacDonald, J. S. 1963. 'Agricultural organization, migration and labour militancy in rural Italy', Economic History Society, 16: 61-75.

[10] Rasmussen, L. L. 1996. Earth community, earth ethics (Orbis Books Maryknoll, NY).
[11] Startups, Groohan Solutions for. 2017. 'What is Innovation and Why Need Innovation'. http://groohan.com/content/.

[12] Ariza, C. R., Diana, L. S., Bladimir, G., 2013. Measuring Innovation in Agricultural Firms: A Methodological Approach. The Electronic Journal of Knowledge Management, 11 (3), 185-198.

[13] Demiryurek K., 2014. Agricultural Knowledge and Innovation Systems and Social Communication Networks. Ondokuz Mayıs University, Faculty of Agriculture, Department of Agricultural Economics, 55139 Kurupelit, Samsun, Turkey, 23.

[14] Abacı N. İ., Demiryürek K., Emir M., Çağatay Y., (2015).Effect of Dairy Cattle Breeders' Association (DCBA) Membership on Sustainability of Innovations in Samsun Province of Turkey. Conference: 2nd ICSAE 2015 International Conference on Sustainable Agriculture and Environment, Turkey (pp. 1-4). Konya.

[15] Abdurahman, M. A., Demiryürek, K., \& Abac1, N. İ. (2016). The Comparison of Agricultural Knowledge and Information Systems (Akis) For Adopters and NonAdopters of Good Agricultural Practices in Bafra District of Samsun, Turkey. Turkish Journal of Agriculture-Food Science and Technology, 4(12), 1092-1103.

[16] Khaliq, A. J. A., \& Boz, İ. (2018). The Role of Agriculture in the Economy of Afghanistan. PROCEEDINGS BOOK, 192.

[17] Khaliq, A. J. A., \& Boz, I. (2019). Evaluating Market Structures and Credit Services for Small Scale Almond Producers in the Samangan and Balkh Provinces, Afghanistan. Asian Journal of Agricultural Extension, Economics \& Sociology, 1-8. 